\title{
Influence of Metabolic Syndrome in Low Back Pain in Benin People
}

\author{
Zomalheto Zavier*, Gounongbe Marcelle, Dossou-Yovo Hilaire \\ Rheumatology Department of National Hospital, University Hubert Koutoukou Maga, Cotonou, Benin \\ Email: ^zozaher@yahoo.fr
}

How to cite this paper: Zavier, Z., Marcelle, G. and Hilaire, D.-Y. (2017) Influence of Metabolic Syndrome in Low Back Pain in Benin People. Open Journal of Rheumatology and Autoimmune Diseases, 7, 153-157. https://doi.org/10.4236/ojra.2017.73015

Received: June 26, 2017

Accepted: August 5, 2017

Published: August 8, 2017

Copyright (C) 2017 by authors and Scientific Research Publishing Inc. This work is licensed under the Creative Commons Attribution International License (CC BY 4.0).

http://creativecommons.org/licenses/by/4.0/ cC) (†) Open Access

\begin{abstract}
Objective: To determine the frequency and impact of metabolic syndrome (MS) in patients with low back pain in rheumatology unit in Benin. Patients and Methods: Analytic cross-sectional study conducted between June and December 2016 in the rheumatology hospital unit of National Hospital University Hubert Koutoukou Maga of Cotonou. 82 patients with mechanical low back pain were selected. The prevalence of MS was defined using the criteria of the International Diabetes Federation 2005. The data were analyzed using epi data and SPSS17.0 software. Results: The mean age was $50.4 \pm 14.9$ [12 90] years. The sex ratio was 0.82. $29.3 \%$ patients have met diagnostic criteria for MS. The mean duration of back pain was $40 \pm 17.2$ [3 - 120] days. Diseases associated with low back pain were as follow: lumbar intervertebral disk degeneration (34.1\%), disk herniation (13.4\%), facet joint arthrosis (18.3\%), degenerative spondylolisthesis (11\%), degenerative lumbar spinal stenosis (6.1\%) and related forms (17.1\%). MS observed in 24 patients was characterized by the frequent association of abdominal obesity (24 cases), arterial hypertension (22 cases), HDL hypocholesterolemia (8 cases), hyperglycemia (12 cases) or hypertriglyceridemia ( 7 cases). The presence of the MS was associated with a decreased response to the medical treatment $(\mathrm{p}<0.01)$. Conclusion: The MS is frequent in patients with low back pain in rheumatology unit at Cotonou and influence the treatment response. The management of these patients must be integrated into a multidisciplinary approach including the rheumatologist and nutritionist.
\end{abstract}

\section{Keywords}

Low Back Pain, Metabolic Syndrome, Cotonou

\section{Introduction}

According to the International Federation of Diabetes in 2005, metabolic 
syndrome (MS) is defined by the presence of several metabolic abnormalities (hyperglycemia, Hypertension, HDL hypocholesterolemia, hypertriglyceridemia, abdominal fat) [1]. It's a frequent syndrome in both less developed and well developing countries. Its association with osteoarthritis is common. obesity plays an important role in the metabolic syndrome and affects both cardiovascular and musculoskeletal pathologies. Obesity increases the risk of radiographic osteoarthritis. The association with hip and hand osteoarthritis is weaker, but it implies that excess adipose tissue produces humoral factors, altering articular cartilage metabolism [2] [3]. It has been postulated that the leptin system could be a link between metabolic abnormalities in obesity and increased risk of osteoarthritis [2] [3] [4]. In black Africa, obesity is seen as a sign of wealth. Its frequency is increasingly high in the Benin population and its prevalence reaches nearly $20 \%$ of the population [5]. Much work has been devoted to the influence of this syndrome on knee osteoarthritis [6]. Low back pain is the first pattern in rheumatology in Benin. It predominates in the young adult, the elderly and in both sexes. And its relationship with the metabolic syndrome is not known in our country. The aim of this study was to determine the frequency and impact of metabolic syndrome (MS) in patients with low back pain in rheumatology Unit in Benin.

\section{Patients and Methods}

We made an analytic cross-sectional study conducted between June and December 2016 in rheumatology hospital unit of National Hospital University Hubert Koutoukou Maga of Cotonou. Eighty-two (82) patients with mechanical low back pain were recruited exhaustively for 12 months. The prevalence of MS was defined using the criteria of the International Diabetes Federation 2005: waist > $94 \mathrm{~cm}$ in men or $>80 \mathrm{~cm}$ in women, associated with at least two of following factors:

- Triglycerides $(\mathrm{TG})>1.5 \mathrm{~g} / \mathrm{L}$,

- HDL cholesterol $<0.4 \mathrm{~g} / \mathrm{L}$ in men and $<0.5$ in women,

- Systolic blood pressure $>130 \mathrm{mmHg}$ or diastolic blood pressure $>85 \mathrm{mmHg}$,

- Glycemia $>1 \mathrm{~g} / \mathrm{L}$.

Patients included in the study met the following criteria:

- To be followed in the rheumatology hospital unit during the study period,

- Had submitted chronic low back pain (more than three months),

- Having made the X-ray and Scanner of lumbar spine and the metabolic laboratory tests (glycemia, TG, cholesterol),

- Having honored the appointment of follow-up visit for 6 months.

Patients who did not realized the diagnostic test were not include in the study The data were analyzed using epi data and SPSS 17.0 software.

\section{Results}

The mean age of the patients was $50.4 \pm 14.9$ [12 - 90] years. The sex ratio was 0.82 (37 men/45 women). Twenty-four (29.3\%) patients have met diagnostic 
criteria for MS. The mean duration of back pain was $40 \pm 17.2$ [3 - 120] days. Diseases associated with low back pain are summarized in Figure 1.

MS observed in 24 patients was characterized by the frequent association of abdominal fat with the other items summarized in Figure 2.

Presence of the MS was associated with a decreased response to the medical treatment after three months $(\mathrm{p}<0.01)$. Table 1 highlights correlation between MS and low back pain.

\section{Discussion}

The high prevalence of metabolic syndrome, the mean age and female predominance in our series were observed in other African works [7] [8] [9] [10]. The prevalence of MS is more than $27.3 \%$ found by Oniakitan, et al. in Togo [7] and

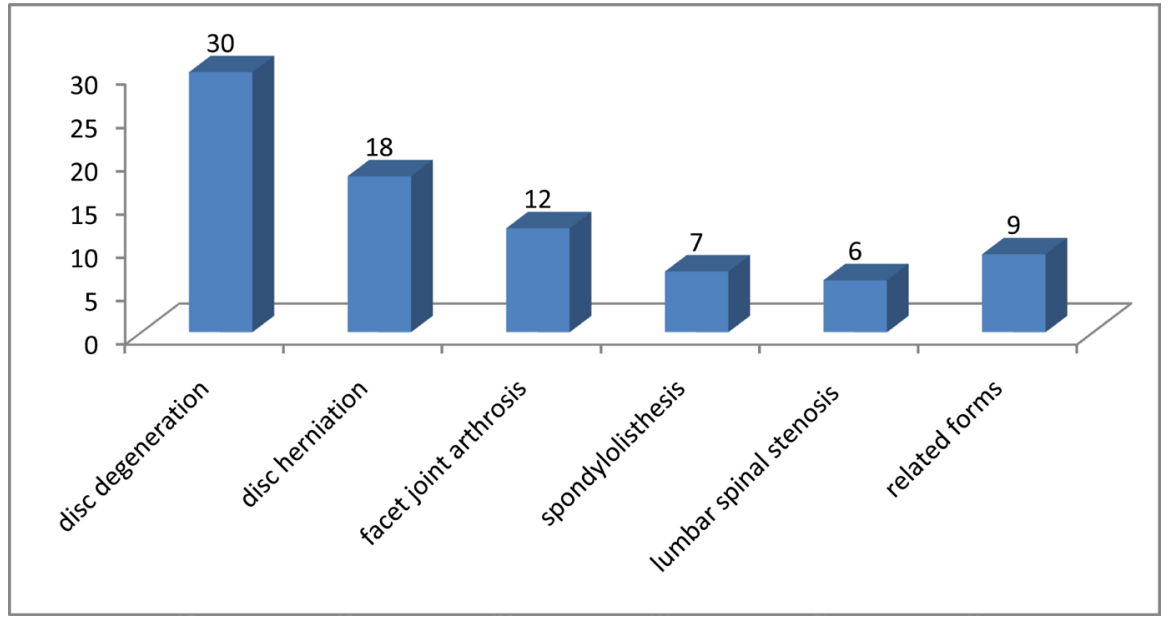

Figure 1. Etiology of low back pain in the unit.

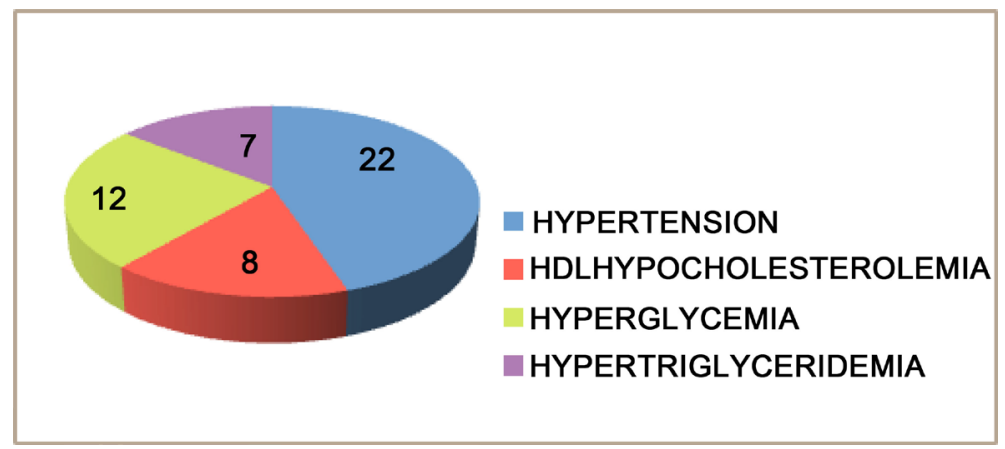

Figure 2. Distribution of metabolic syndrome in the patients.

Table 1. Influence of metabolic syndrome on response of treatment.

\begin{tabular}{|c|c|c|c|c|}
\hline \multirow{2}{*}{$\begin{array}{l}\text { Residual Pain after medical } \\
\text { treatment }\end{array}$} & \multicolumn{2}{|c|}{ Metabolic Syndrome } & \multirow{2}{*}{ Total } & \multirow{2}{*}{$\begin{array}{l}\text { Statistic } \\
\text { Test }\end{array}$} \\
\hline & 2abnomalities & $>$ 2abnomalities & & \\
\hline$<25 \%$ & 2 & 5 & 7 & \\
\hline$>75 \%$ & 14 & 3 & 17 & $\begin{aligned} \mathrm{X}^{2} & =6.454 \\
\mathrm{P} & <0.01\end{aligned}$ \\
\hline Total & 16 & 8 & 24 & \\
\hline
\end{tabular}


less than the 58.7\% found by El Ouadih et al. in Morocco [8]. All this clearly denotes the importance of MS in developing countries. Female predominance is explained by the complex of superiority of men who take time to manifest their pain in our country.

In our study, more abnormalities of metabolic syndrome increased, more the response of treatment was bad $(\mathrm{P}>0.001)$. Few studies have been conducted showing association between chronic low back pain and metabolic syndrome and risk factors identified on metabolic syndrome were various [8] [9] [10] [11]. According to Duroz, et al., high body mass index, chronic low back pain, old age was associated with bad evolution of back pain [8]. For Ono, association was significantly in women and there was no association between low back pain and metabolic syndrome in men [9]. Vismara, et al. showed that obese individuals with chronic low back pain presented higher degree of spinal impairment when compared to those without chronic low back pain [10]. On the Contrary, Yip, et al. found no association between excessive weight, tall stature and an increased risk of low back pain in Hong Kong Chinese middle-aged women [11]. Conversely, their results indicated that a high waist to hip ratio was associated with a lower risk of severe low back pain but they didn't evaluate the association between underweight/obesity, bone mass density and low back pain.

Although the size of our diet is low, it traces the influence of the metabolic syndrome on the presence of low back pain. Large-scale studies could be conducted to confirm these results. Nevertheless, it is possible to understand that the management of patients suffering from low back pain must be done according to a multidisciplinary approach.

\section{Conclusion}

Metabolic syndrome was frequent in patients with low back pain in rheumatology unit at Cotonou and influenced the treatment response. For this reason patients with low back pain can be screened for metabolic syndrome and preventive measures can be taken. The management of these patients must be integrated into a multidisciplinary approach including the rheumatologist and nutritionist.

\section{Conflict of Interest Statement}

The authors declare no conflict of interest in relation with this article. Ethical approval was obtained for this work.

\section{References}

[1] Eckel, R.H., Grundy, S.M. and Zimmet, P.Z. (2005) The Metabolic Syndrome. Lancet, 365, 1415-1428. https://doi.org/10.1016/S0140-6736(05)66378-7

[2] Magliano, M. (2008) Obesity and Arthritis. Menopause International, 14, 149-154. https://doi.org/10.1258/mi.2008.008018

[3] Yoshimura, N., Muraki, S., Oka, H., Kawaguchi, H., Nakamura, K. and Akune, T.L. (2011) Association of Knee Osteoarthritis with the Accumulation of Metabolic Risk 
Factors Such as Overweight, Hypertension, Dyslipidemia, and Impaired Glucose Tolerance in Japanese Men and Women: The ROAD Study. The Journal of Rheumatology, 38, 921-930. https://doi.org/10.3899/jrheum.100569

[4] Engström, G., Gerhardsson de Verdier, M., Rollof, J., Nilsson, P.M., Lohmander, L.S. (2009) C-Reactive Protein, Metabolic Syndrome and Incidence of Severe Hip And Knee Osteoarthritis. A Population-Based Cohort study. Osteoarthritis Cartilage, 17, 168-173. https://doi.org/10.1016/j.joca.2008.07.003

[5] Ministry of Health of Benin, National Control for No Transmissible Disease (2007) Final Report of the STEPS Survey Cotonou, Benin. WHO, Geneva, 1-101.

[6] Oniakitan, O., Fianyo, E., Kakpovi, K., Tagbor, K.C., Koffi-Tessio, V.E., Houzou, P. and Mijiyawi, M. (2012) Osteoarthritis and Metabolic Syndrome in Rheumatology Unit in Lome. Revue du Rhumatisme, 79, 271.

[7] El Ouadih, M., Rachidi, W., Janani, S. and Mkinsi, O. (2012) Knee Osteoarthritis and Metabolic Syndrome. La Revue de Médecine Interne, 33S, A90-A198.

[8] Duroz, M.T., Turan, Y., Gürgan, A. and Deveci, H. (2012) Evaluation of Metabolic Syndrome in Patients with Chronic Low Back Pain. Rheumatology International, 32, 663-667. https://doi.org/10.1007/s00296-010-1693-x

[9] Ono, R., Yamazaki, S., Takegami, M., et al. (2012) Gender Difference in Association between Low Back Pain and Metabolic Syndrome: Locomotive Syndrome and Health Outcome in Aizu Cohort Study(LOHAS). Spine, 37, 1130-1137. https://doi.org/10.1097/BRS.0b013e31824231b8

[10] Vismara, L., et al. (2010) Effect of Obesity and Low Back Pain on Spinal Mobility: A Cross Sectional Study in Women. Journal of NeuroEngineering and Rehabilitation, 18, 7-13. https://doi.org/10.1186/1743-0003-7-3

[11] Yip, Y.B., Ho, S.C. and Chan, S.G. (2001) Tall Stature, Overweight and Prevalence of Low Back Pain in Chinese Middle-Aged Women. International Journal of Obesity and Related Metabolic Disorders, 25, 887-892.

https://doi.org/10.1038/sj.ijo.0801557

Scientific Research Publishing

\section{Submit or recommend next manuscript to SCIRP and we will provide best service for you:}

Accepting pre-submission inquiries through Email, Facebook, LinkedIn, Twitter, etc. A wide selection of journals (inclusive of 9 subjects, more than 200 journals)

Providing 24-hour high-quality service

User-friendly online submission system

Fair and swift peer-review system

Efficient typesetting and proofreading procedure

Display of the result of downloads and visits, as well as the number of cited articles

Maximum dissemination of your research work

Submit your manuscript at: http://papersubmission.scirp.org/

Or contactojra@scirp.org 